\title{
Retraction Note: Mast cells are the main interleukin 17-positive cells in anticitrullinated protein antibody-positive and -negative rheumatoid arthritis and osteoarthritis synovium
}

\author{
Jolien Suurmond ${ }^{1 *}$, Annemarie L. Dorjée ${ }^{1}$, Mariëtte R. Boon ${ }^{1}$, Edward F. Knol ${ }^{2}$, Tom W. J. Huizinga', \\ René E. M. Toes ${ }^{1}$ and Annemie J. M. Schuerwegh ${ }^{1}$
}

\section{Retraction}

The authors retract this article [1] following an investigation by Leiden University Medical Centre into the research activities of the last author. The investigation identified a discrepancy between the data reported in the article and the original collected data. The investigation committee concluded that this undermined the scientific basis of the publication and advised that the publication should be retracted.

The online version of this article contains the full text of the retracted article as electronic supplementary material (Additional file 1).

\section{Additional file}

Additional file 1: Mast cells are the main interleukin 17-positive cells in anticitrullinated protein antibody-positive and -negative rheumatoid arthritis and osteoarthritis synovium. (PDF $1320 \mathrm{~kb}$ )

\section{Author details}

'Department of Rheumatology, Leiden University Medical Center, PO Box 9600, Albinusdreef 2, C1-R, NL-2300 RC, Leiden, The Netherlands. 'Department of Dermatology/Allergology, University Medical Center Utrecht, Heidelberglaan 100, NL-3584 CX, Utrecht, The Netherlands.

Received: 1 November 2015 Accepted: 2 November 2015

Published online: 09 December 2015

\section{Reference}

1. Suurmond J, Dorjée AL, Boon MR, Knol EF, Huizinga TWJ, Toes REM, et al. Mast cells are the main interleukin 17-positive cells in anticitrullinated protein antibody-positive and -negative rheumatoid arthritis and osteoarthritis synovium. Arthritis Res Ther. 2011;13:R150.

* Correspondence: j.suurmond@lumc.n

'Department of Rheumatology, Leiden University Medical Center, PO Box 9600, Albinusdreef 2, C1-R, NL-2300 RC, Leiden, The Netherlands
Submit your next manuscript to BioMed Central and take full advantage of:

- Convenient online submission

- Thorough peer review

- No space constraints or color figure charges

- Immediate publication on acceptance

- Inclusion in PubMed, CAS, Scopus and Google Scholar

- Research which is freely available for redistribution

Submit your manuscript at www biomedcentral.com/submit 